\title{
The Role of Meaningful Work in Employees' Work-Related and General Well-being
}

\author{
Dr. Jessica van Wingerden MBA MCC ${ }^{1,2} \&$ Joost van der Stoep MSc ${ }^{1,3}$ \\ ${ }^{1}$ Schouten Global, Centre of Research, Knowledge and Innovation, The Netherlands \\ ${ }^{2}$ Erasmus University Rotterdam, The Netherlands \\ ${ }^{3}$ VU University Amsterdam, The Netherlands \\ E-mail: Jessica.vwingerden@sn.nl; jessica.vanwingerden@gmail.com
}

Received: July 28, 2017 Accepted: August 18, 2017 Online published: September 14, 2017 doi:10.5296/ijhrs.v7i4.11611

URL: https://doi.org/10.5296/ijhrs.v7i4.11611

\begin{abstract}
This study examines the impact of meaningful work on employees' work-related well-being (measured as high levels of work engagement and low levels of burnout) and subsequently on employees' general well-being (that is happiness). Based on the literature on meaningful work and the job demands-resources theory, we hypothesize that meaningful work has a positive relationship with an employee's general well-being and that this relation is mediated by both increased levels of work engagement and decreased levels of burnout. In order to test the hypothesized relations, we conducted a bootstrapping analysis using a sample of 1892 employees working in various organizations and occupations in The Netherlands. The results of the analysis provide support for the hypothesized relations, indicating an important role for meaningful work in the on-going pursuit of well-being at home and at work. The main theoretical, practical, and methodological implications of this study are discussed.
\end{abstract}

Keywords: Meaningful work, Work Engagement, Burnout, Happiness, Work-related well-being, General well-being

\section{Introduction}

People spend a significant time of their life at work (Blustein, 2008), and in the incessant human pursuit of happiness, work has taken up a key position as it is an important source of purpose, meaning and identity (Pratt \& Ashforth, 2003; Rosso, Dekas, \& Wrzesniewski, 2010). Meaningful work - defined as work that is experienced as particularly significant and holding positive meaning for an individual (Rosso et al., 2010, p95) - has been linked to both 
well-being and performance (e.g. Grant, 2008; May, Gilson, \& Harter, 2004). The importance of meaningful work is reflected in the fact that contemporary employees increasingly value meaningful work ahead of income, job security, promotions or working hours (Cascio, 2003). As a result, there is a need for organizations to actively cultivate the meaningfulness of work in order to retain and attract the most talented employees (Havener, 1999). This all makes meaningful work a key issue for both scholars and practitioners in the field of work and organizational psychology. However, despite a growing interest in the topic of meaningful work, little is known about the role that meaningful work plays in today's volatile, uncertain, complex, and ambiguous world.

Over the last decades, work and the way work is done have changed significantly (Grant \& Parker, 2009). Due to technological developments, increasing globalization and economical changes, new jobs have emerged while more traditional jobs have disappeared or have been drastically transformed (World Economic Forum, 2017). These transformations may have both positive and negative implications for contemporary employees. On the one hand, it presents opportunities to develop new skills and use different strengths at work (World Economic Forum, 2016). This challenges employees and make them thrive. On the other hand, the transformation of work increases the complexity of work, potentially harming the work experience and well-being of employees (Cartwright \& Holmes, 2006). In a changing environment, adding value for others and making a difference may not be self-evident. It is therefore crucial to advance our understanding of the role that meaningful work plays in contemporary organizations. More precisely, to know how meaningful work affects employee well-being both at work and at home.

The main aim of this study is therefore to increase our understanding of the impact of meaningful work on employee well-being in the modern workplace, and subsequently at home (that is happiness). A theory that helps us to understand the impact of work on employee well-being is the Job Demands-Resources (JD-R) theory (Bakker \& Demerouti, 2014). The JD-R theory provides a theoretical framework that describes how psychological states like work engagement and burnout are associated and predict important personal and organizational outcomes. In work and organizational psychology, both the positive (e.g., work engagement; Hakanen, Bakker, \& Schaufeli, 2006; Tadic, Bakker, \& Oerlemans, 2013) and negative facets of work (e.g., job stress; Garrick, Mak, Cathcart, Winwood, Bakker, \& Lushington, 2014) are subjects of research. With this study, we explore and test the relationship between meaningful work and employee general well-being (happiness) and how this relationship is mediated by work-related well-being (measured as both work engagement and burnout). We finish with a discussion of the main theoretical, practical and methodological implications of the present study.

\section{Theory and Hypotheses Development}

\subsection{The Importance of Meaningful Work}

Meaningful work refers to work that employees perceive as significant in that it serves an important purpose (Pratt \& Ashforth, 2003). In the field of social sciences, meaningful work is often described as the job characteristic that employees value the most (Grant, 2007; 
Harpaz \& Fu, 2002). Some scholars make a stronger statement about meaningful work and regard it as a fundamental right (Frankl, 1959; Yeoman, 2014). Meaningless work, in contrast, is described by scholars as disengaging, alienating and disfranchising (Nair \&Vohra, 2009; Shantz, Alfes, \& Truss, 2014).

An employee considers his or her work as meaningful when the work goal or purpose is in line with his or her own ideals or standards (Thomas \& Velthouse, 1990). Such alignment occurs when there's a fit between the requirements of work and an employee's beliefs, values and behaviors (Hackman \& Oldham, 1980; Chalofsky, 2003). It is therefore important to note that the experience of meaningful work more depends on the subjective interpretation of work by the employee and less on the objective reality (Thomas \& Velthouse, 1990). All in all, the psychological meaningfulness of work refers to the cognitive experience of work by employees in a way that work is perceived as significant and meaningful. Although some people are more likely to experience meaningful work simply because they possess certain personality traits (e.g., calling orientation; Wrzesniewski, McCauley, Rozin, \& Schwartz, 1997), most people have the tendency to pursue meaning in their life (Frankl, 1984).

The meaning attached to work and employees' experience of meaningful work leads to positive personal and work-related outcomes (see Baumeister \& Vohs, 2002; Neck \& Milliman, 1994; Pratt \& Ashforth, 2003; Wrzesniewski \& Dutton, 2001). Research revealed that meaningful work is related to retention of key employees, effective management of change, greater organizational commitment, organizational performance and employee engagement (Holbeche \& Springett, 2004; May et al., 2004; Milliman, Czaplewski, \& Ferguson, 2003; Neck \& Milliman, 1994; Olivier \& Rothmann, 2007). Further, a lack of meaningful work has been linked to negative outcomes, like employee cynicism (Anderson, 1996; Holbeche \& Springett, 2004). In order to effectively understand the role of meaningful work in the development of employee well-being it is therefore crucial to look more closely at the processes through which meaningful work affects work-related well-being. An influential theory that helps us to understand the influence of the work environment on employee well-being is the Job Demands-Resources Theory (Bakker \& Demerouti, 2014).

\subsection{Meaningful Work and Employee Well-being}

Over the past decade, JD-R theory has been used to understand and predict employee well-being among a wide range of sectors and in all types of occupations around the world (for reviews, see Bakker \& Demerouti, 2014; Bakker, Demerouti, \& Sanz-Vergel, 2014). One key assumption of JD-R theory is that all jobs are characterized by job demands and job resources. Job demands are aspects of the job that require employees' effort and energy and therefore come with certain costs (Demerouti, Bakker, Nachreiner, \& Schaufeli, 2001). Examples of job demands are work pressure, role-conflict, and facing emotionally demanding situations. Job resources refer to those aspects of the job that are functional for employees in achieving their work goals. Therefore, they can be used to reduce the impact of job demands and the associated costs. Examples of job resources are autonomy, constructive feedback and opportunities to learn and grow. Combined, both job demands and resources influence how employees perceive their work. 
According to the JD-R theory, the job demands and resources faced by employees in their work environment elicit two independent psychological processes - a health impairment process and a motivational process. First, the health impairment process begins with high job demands that may deplete employees' energetic resources and lead to fatigue and health problems (Hakanen, Bakker, \& Schaufeli, 2006). This subsequently may lead to stress and even burnout, which entails two dimensions; exhaustion and cynicism (Schaufeli \& Taris, 2005). Exhaustion reflects the stress dimension of burnout and triggers employees to detach themselves from work. This process of employee detachment is often accompanied with a cynical attitude towards work. We argue that the experience of psychological meaningful work serves as a buffer against burnout. On the one hand this is because meaning leads to stability (Cartwright \& Holmes, 2006), so that employees are able to better cope with their job demands. On the other hand, because meaningful work reflects a deep connection between oneself and the work, this diminishes the likelihood of detachment from work. Both the increased stability and increased connection limit the risk of employees become burnout.

In contrast to the health impairment process, the motivational process starts with job resources that have motivational potential and lead to high levels of work engagement and low levels of cynicism (Demerouti \& Bakker, 2011). Schaufeli and Bakker (2004, p. 295) defined work engagement as "the positive, fulfilling and work-related state of mind that is characterized by vigor, dedication, and absorption". Employees who are vigorous, experience high levels of energy and mental resilience at work. Employees who are dedicated to their work, are involved in their work and experience a sense of significance and joy. Finally, employees who are absorbed are fully concentrated and immersed in their work. Engaged individuals are healthier than their less-engaged colleagues and experience more active and positive emotions (Bakker \& Demerouti, 2014). We argue that the experience of meaningful work by employees ignites a fire within, which leads to higher levels of work engagement.

Following the reasoning of these health-impairment and motivational processes of the JD-R theory, we argue that the experience of meaningful work mirrors a deep personal connection between an employee and his or her work, which subsequently influence levels of work engagement and burnout. In order to better understand these processes, consider caregivers in the elder care (see Blomberg, James, \& Kihlgren, 2013; Wilson \& Davies, 2009). When caregivers perceive their work as meaningful, they are more invested in their work, and more determined to provide better care. This leads, for example, to the active pursuit of additional valuable information from caretaker and his or her immediate social circle (for example, family, friends, or even former caregivers) in order to better adhere to the specific preferences or needs of the caretaker (e.g. DeHart, Webb, \& Cornman, 2009). Likewise, the caregivers may choose to enrol for additional training or courses. In this example meaningful work thus results in increased access to information, feedback, or training; all relevant job resources and important predictors for well-being at work (May, et al., 2004). The personal connection with work also diminishes potential burnout as it protects against exhaustion and cynicism. This is because the investment leads to higher levels of competence and self-efficacy by the employee. So in conclusion, meaningful work positively affects an employee's level of well-being at work; measured in higher levels of work engagement and lower levels of 
burnout.

\subsection{The Pursuit of Happiness}

All things considered, meaningful work is an important predictor of employee well-being. On top of this, these positive effects may even spill-over to the private life of employees (Bakker $\&$ Demerouti, 2008). General well-being, or happiness, is often considered as the ultimate goal in life and is defined as the experience of a sense of joy and positive well-being, combined with a sense that one's life is good, worthwhile and meaningful (Seligman, 2002). Happiness is not the same as optimal functioning, but it is a closely related phenomenon. Happiness can be developed via a hedonic or a eudaimonic route. The hedonic route is concerned with the act of seeking pleasure and/or avoiding pain, while the eudaimonic route is associated with a deeper personal level of meaning and engagement (Ryan \& Deci, 2000; Huta \& Ryan, 2010; Huta \& Waterman, 2014). In this study we hypothesize that meaningful work leads to happiness in three ways; via increased work engagement, via decreased burnout, and directly because the experience of meaningful work in itself adds an element of meaning and contribution by the employee (see figure 1).

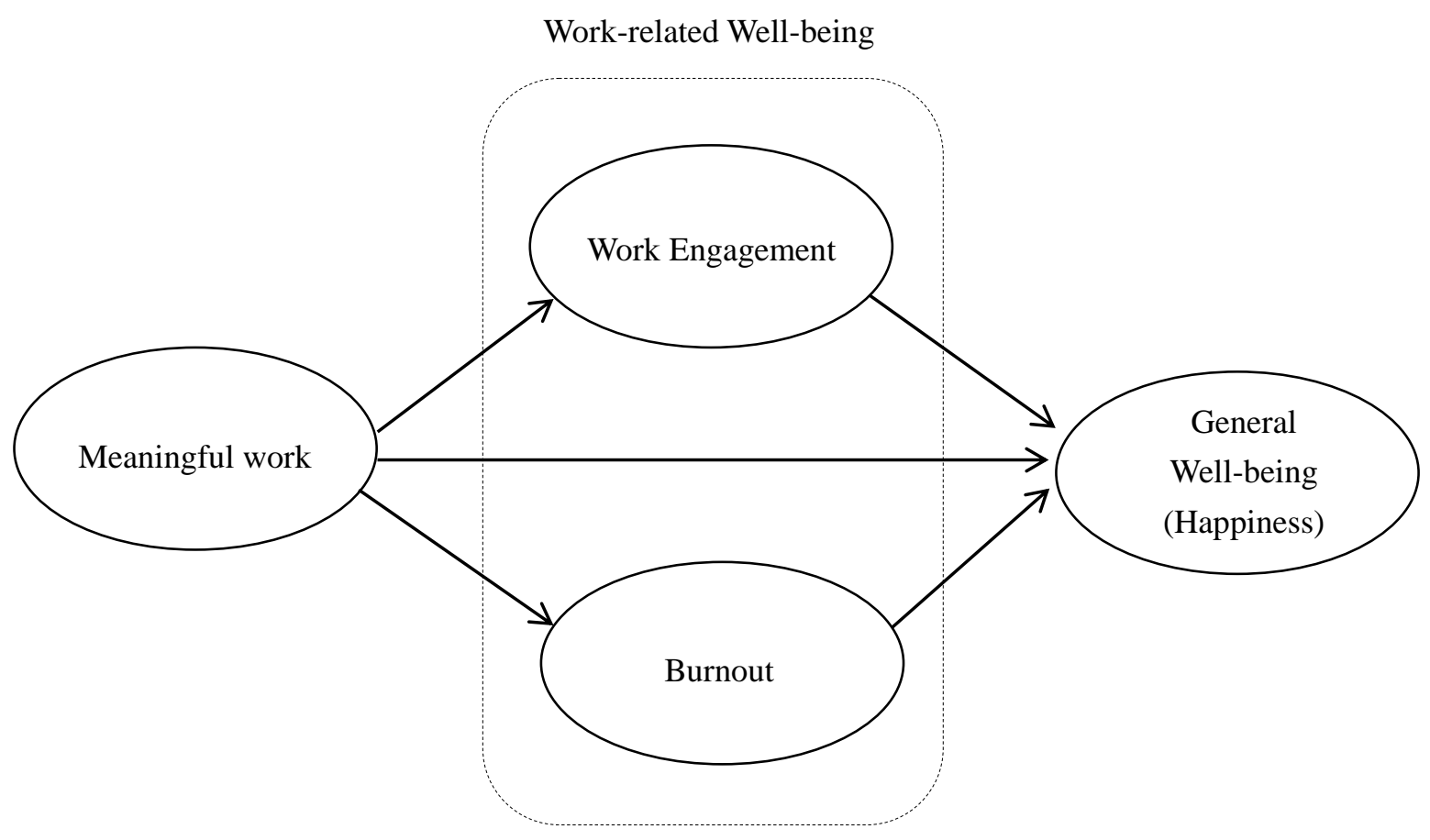

Figure 1. Model meaningful work and well-being

In the sections above, we have stressed out how meaningful work leads to higher levels of work engagement (the motivational process) and lower levels of burnout (the health impairment process). These processes are in line with the hedonic approach to happiness that focuses on seeking pleasure and avoiding pain. Therefore, we hypothesize that both high 
levels of work engagement and low levels of burnout mediate the relationship with general well-being. Meaningful work leads to general well-being, because engaged employees tend to experience more positive emotions and higher levels of joy, enthusiasm and happiness (Bakker \& Demerouti, 2008). Therefore, we expect a positive relationship between meaningful work and happiness via increased work engagement. Furthermore, meaningful work leads to general well-being, because lower levels of exhaustion and cynicism (the elements of burnout) are important predictors of health and a better health has been repeatedly associated with higher levels of happiness (Argyle, 2013; Veenhoven, 2008). Therefore we expect a positive relationship between meaningful work and well-being (happiness) via decreased burnout.

Last, following the eudaimnoic approach to happiness we argue that there is also a direct relationship between meaningful work and happiness. This hypothesized relation is grounded in the idea that people have the tendency to pursue meaningful work and to contribute to society. People have a desire to benefit other people; to do meaningful work, and to do work that matters (Huta \& Waterman, 2014). In other words, people pursue a life worth living. The experience of meaningful work makes that an employee feels that his or her life is meaningful, and this subsequently leads to higher overall levels of well-being. All things considered, we hypothesize that within contemporary organizations meaningful work affects happiness in three ways; via increased work engagement, via decreased burnout, and directly. This leads to the following three hypotheses.

Hypothesis 1: Meaningful work has a positive relation with happiness and this relation is partly mediated by increased levels of work engagement.

Hypothesis 2: Meaningful work has a positive relation with happiness and this relation is partly mediated by decreased levels of burnout.

Hypothesis 3: Meaningful work has a direct and positive relation with happiness.

\section{Methods}

\subsection{Procedure and Participants.}

We collected data using an online survey. The study was announced on a well-known Dutch career development website as well as through various social media channels. Respondents were invited to participate on a voluntary basis and directed to the survey through an online link. Data has been collected in accordance with the ethical guidelines of the American Psychological Association and the Dutch Association of Psychologists. As such, (1) participation was completely voluntary, (2) data collection through a self-report survey is exempted from an institutional ethics committee's approval, and (3) the respondents did not receive any monetary compensation for their contribution. Informed consent was given by clicking on the "Finish" button on the last page of the survey.

The survey was in Dutch and available for 4 weeks. In total, 1892 employees filled out the survey. A majority of the sample was female $(67 \%)$ and the mean age of the participants was 43.4 years $(S D=10.6)$. Most participants $(77 \%)$ reported that they possessed at least a 
bachelor's degree. Various sectors were represented, with most participants working in the public sector $(17 \%)$, health care $(21 \%)$, education $(16 \%)$, professional services $(15 \%)$, finance $(9 \%)$, industry (12\%), and information technology $(10 \%)$.

\subsection{Measures}

The internal consistency reliabilities for all measures of the present study are presented on the diagonal in Table 1.

Meaningful work was measured using the Positive Meaning subscale of the Work And Meaning Inventory (WAMI; Steger, Dik, \& Duffy, 2012). All 4 items were scored on a five-point Likert scale ranging from 1 (absolutely untrue) to 5 (absolutely true). Positive meaning (PM) was assessed with four items, including "I understand how my work contributes to my life's meaning".

Work engagement was measured with the validated nine-item Utrecht Work Engagement Scale (UWES; Schaufeli, Bakker \& Salanova, 2006). Example items are: "At work, I am bursting with energy" (vigor,), "I am enthusiastic about my job" (dedication), and "I am immersed in my work" (absorption). Participants used a seven-point frequency scale, ranging from (0) never to (6) always.

Burnout was measured with two scales from the Maslach Burnout Inventory-General Survey (Schaufeli, Leiter, Maslach, \& Jackson, 1996): emotional exhaustion (5 items) and depersonalization (4 items). An example item is "I doubt the significance of my work". The items were scored on a 7-point frequency rating scale ranging from (0) never to (6) daily.

Happiness was measured with the 8-item Oxford Happiness Questionnaire (Hills \& Argyle, 2002). An example item is "I feel that life is very rewarding". Participants used a six-point frequency scale, ranging from (0) strongly disagree to (6) strongly agree.

\section{Results}

\subsection{Descriptive Statistics}

The baseline characteristics of the study population are presented in Table 1. The means, standard deviations, reliabilities, and correlations, between all study variables are displayed in Table 2. Our central prediction is that meaningful work is related to both employees' work-related well-being and general well-being. We propose that meaningful work is positively related to general well-being via work engagement (Hypothesis 1), and via burnout (Hypothesis 2). In addition, we propose that meaningful work is directly positively related to general well-being (Hypothesis 3). To test Hypothesis 1 to 3, we examined the direct and indirect effects using Hayes' PROCESS macro (Hayes, 2013). 
Table 1. Baseline characteristics of the study population $(n=1892)$

\begin{tabular}{llll}
\hline Characteristic & $\mathrm{n}(\%)$ & Characteristic & $\mathrm{n}(\%)$ \\
\hline Sex & & Supervisory position & \\
Woman & $1268(67)$ & Yes & $511(27)$ \\
Men & $624(33)$ & No & $1381(73)$ \\
& & & \\
Age & & Martial status & \\
26-35 years & $265(14)$ & Married & $870(46)$ \\
36-45 years & $795(42)$ & Unmarried & $492(26)$ \\
46-55 years & $662(35)$ & Cohabiting & $322(17)$ \\
56-72 years & $170(9)$ & Divorced or widowed & $132(7)$ \\
& & & \\
Professional sector & & Job tenure & \\
Education & $303(16)$ & $0-3$ years & $774(41)$ \\
Healthcare & $397(21)$ & $4-6$ years & $340(18)$ \\
Public sector & $322(17)$ & $7-10$ years & $321(17)$ \\
Industry & $227(12)$ & $11-15$ years & $189(10)$ \\
Professional services & $284(15)$ & $>15$ years & $264(14)$ \\
Finances & $170(9)$ & & \\
ICT & $189(10)$ & & \\
\hline
\end{tabular}

Table 2. Means, standard deviations, correlations and Cronbach's alpha of the study variables

\begin{tabular}{lccccccccc}
\hline & $M$ & $S D$ & 1 & 2 & 3 & 4 & 5 & 6 & 7 \\
\hline 1. Meaningful work & 3.42 & 0.92 & $(.90)$ & & & & & & \\
2. Cynicism & 3.14 & 1.48 & $-.73^{* *}$ & $(.92)$ & & & & & \\
3. Emotional exhaustion & 3.09 & 1.36 & $-.55^{* *}$ & $.75^{* *}$ & $(.93)$ & & & & \\
4. Vigor & 4.06 & 1.31 & $.70^{* *}$ & $-.72^{* *}$ & $-.66^{* *}$ & $(.89)$ & & & \\
5. Dedication & 4.26 & 1.39 & $.81^{* *}$ & $-.76^{* *}$ & $-.57^{* *}$ & $.84^{* *}$ & $(.91)$ & & \\
6. Absorption & 4.33 & 1.23 & $.60^{* *}$ & $-.57^{* *}$ & $-.44^{* *}$ & $.80^{* *}$ & $.74^{* *}$ & $(.82)$ & \\
7. Happiness & 4.06 & 0.84 & $.51^{* *}$ & $-.54^{* *}$ & $-.61^{* *}$ & $.58^{* *}$ & $.53^{* *}$ & $.41^{* *}$ & $(.80)$ \\
\hline
\end{tabular}

Note. $* p<.05, * * p<.01$

\subsection{Meaningful Work and Well-being}

In Hypothesis 1, we proposed that meaningful work is positively related to employees' general well-being and that this relation is partly mediated by increased levels of work engagement. In order to test Hypothesis 1, we conducted a regression analysis using PROCESS model 3 (Hayes, 2013), with calculation of 1000 bias-corrected bootstrap 95\% confidence intervals. The results of the analysis revealed a significant positive regression between meaningful work and employees' general well-being via work engagement (Effect $=.2631$, Boot S.E. $=.0228 ; 95 \%$ BCa Cis 1000; LLCI .2173 - ULCI .3064). Hence, the results 
confirm Hypothesis 1.

In hypothesis 2, we proposed that meaningful work is positively related to employees' general well-being and that this relation is partly mediated by decreased levels of burn-out. In order to test Hypothesis 2, we also conducted a regression analysis using PROCESS model 3 (Hayes, 2013), with calculation of 1000 bias-corrected bootstrap 95\% confidence intervals The results of the analysis revealed a significant positive regression between meaningful work and employees' general well-being via burnout (Effect $=.3119$, Boot S.E. $=.0180 ; 95 \%$ BCa Cis 1000; LLCI .2760 - ULCI .3467), Hence, the results confirm Hypothesis 2.

Finally, in Hypothesis 3, we argued that there is also a direct relationship between meaningful work and employees' general well-being. In order to test this Hypothesis, we conducted a linear regression analysis. The results of the analysis revealed a significant positive regression between meaningful work and happiness $(\mathrm{B}=.47, S E=.02, p<.01)$, this finding is in line with the partial mediation tests using PROCESS model 3 (Hayes, 2013) of Hypothesis 1 and 2. All in all, this provides support for Hypothesis 3.

\section{Discussion and Conclusion}

In today's volatile, uncertain, complex, and ambiguous world, work and the way work is done has changed significantly (Bennett \& Lemoine, 2014). These changes in the workplace have resulted in increased demands faced by employees, which often have a negative effect on their health and personal life (Cartwright \& Holmes, 2006). Although meaningful work has been considered a key issues within organizations (Rosso et al., 2010), up till now little was known about how meaningful work affects employee well-being at work and at home. Results of this study demonstrate that meaningful work has a positive relation with general well-being via increased levels of work engagement and decreased levels of burnout. This study further found support for a direct and positive relation between meaningful work and employee's general well-being (that is happiness). All things considered, this study supports our claim that meaningful work is an important contemporary predictor of well-being at home and at work.

\subsection{Theoretical Contribution}

This study advances our understanding of the role that meaningful work plays within contemporary organizations and how meaningful work is linked to well-being at work and at home. In this way, we advanced earlier research of May and colleagues (2004) who focused primarily on the relationship between meaningful work and work engagement. Our research demonstrated that meaningful work indeed leads to higher levels of work engagement, but also to lower levels of burnout. As far as we know, this is the first study that revealed the positive impact of meaningful work on burnout. Employees spend a significant time of their life at work where they have to deal with on-going changes and uncertainty (Bennett \& Lemoine, 2014), potentially harming their health and personal life (Cartwright \& Holmes, 2006). This study showed that meaningful work might play an important role in buffering against these potential health risks. Furthermore, this study revealed that meaningful work even has a positive impact on employees beyond the context of work (Bakker \& Demerouti, 
2008). This study shows that meaningful work not only has a positive impact on well-being at work, but also at home. This implies that meaningful work could potentially benefits society as a whole.

\subsection{Limitations and Avenues for Future Research}

Although this study provides strong evidence for the hypothesized relations and is based on a large sample in a wide variety of industries and occupations, some limitations of our research need to be mentioned. First, the cross-sectional nature of this study is a shortcoming as it limits the causal inference of the study. Future research might want to focus on more longitudinal methods in order to examine the causal relationships among the study variables. Second, although this study is fundamentally depending on employee perceptions, this study heavily rely on self-report measures. As these methods are prone to self-report bias, the results should be interpreted with caution. Future research might explore alternative and more objective ways to measure of the variables of this study (e.g. Podsakoff, MacKenzie, Lee, \& Podsakoff, 2003). Third, although this study uses a large and diverse set of respondents working in a wide variety of occupations and industries. We have only used respondents from The Netherlands. The Netherlands score high in world rankings on happiness (Helliwel, Layard, \& Sachs, 2017), which may affect the results to some degree. Therefore, future research might want to explore the meaningful work - well-being relationship in other countries as well.

\subsection{Practical Implications and Conclusion}

The main practical implication of this study is that the meaningfulness of work matter. It is strongly related to work engagement, burnout, and even overall happiness in life. This makes the cultivation of meaningful work a key issue for managers and policy makers within contemporary organization. Even without the proposed moral obligation for meaningful work (Michaelson, Pratt, Grant, \& Dunn, 2013), or the detrimental costs of burnout (Cartwright \& Holmes, 2006), organizations should actively cultivate the meaningfulness of work. Managers and practitioners can do this by changing the perceptions of the meaningfulness of work by employees. For example, by clearly articulating compelling goals and values, enhancing a sense of belonging, or by influencing and framing how employees look at their work (see Blomberg, James, \& Kihlgren, 2013). Leaders play a special role in the cultivation of meaningful work. They need to be mindful about the impact of meaningful work and actively start a dialogue within the organization in order to make everyone aware of the higher purpose and meaning of the organization.

In conclusion, this study has shed new light on the relationship between meaningful work and employee well-being, both at work and at home. It demonstrates that within today's volatile, uncertain, complex, and ambiguous world, meaningful work operates as a buffer against burnout and as a driver for work engagement. The boost in well-being at work even spills over to life at home, in this way benefiting the society as a whole. We strongly believe in the potential of meaningful work and the merits the cultivation of meaningful work has for employees and organizations. Therefore, we hope this study invites other researcher to explore the role of meaningful work beyond this study, but ultimately we hope this study 
inspire practitioners to actively cultivate the meaningfulness of work within their organizations.

\section{References}

Anderson, L. (1996). Employee cynicism: An examination using a contract violation framework. Human Relations, 49, 1395-1418. https://doi.org/10.1177/001872679604901102

Argyle, M. (2013). The psychology of happiness. Routledge.

Bakker, A. B. (2011). An evidence-based model of work engagement. Current Directions in Psychological Science, 20, 265-269. https://doi.org/10.1177/0963721411414534

Bakker, A.B., \& Demerouti, E. (2008). Towards a model of job engagement. Career Development International, 13, 209-223. https://doi.org/10.1108/13620430810870476

Bakker, A. B., \& Demerouti, E. (2014). Job demands-resources theory. In C. Cooper and P. Chen (Eds.), Wellbeing: A complete reference guide (pp. 37-64). Chichester, UK: Wiley-Blackwell. https://doi.org/10.1002/9781118539415.wbwell019

Bakker, A. B., Demerouti, E., \& Sanz-Vergel, A. I. (2014). Burnout and work engagement: The JD-R approach. Annual Review of Organizational Psychology and Organizational Behavior, 1, 389-411. https://doi.org/10.1146/annurev-orgpsych-031413-091235

Baumeister, R. F., \& Vohs, K. D. (2002). The pursuit of meaningfulness in life.

Bennett, N., \& Lemoine, G.J. (2014). What a difference a word makes: Understanding threats to performance in a VUCA world. Business Horizons, 57, 311-317. https://doi.org/10.1016/j.bushor.2014.01.001

Blomberg, K., James, I., \& Kihlgren, A. (2013). Meanings over time of working as a nurse in elderly care. The Open Nursing Journal, 7, 107-113. https://doi.org/10.2174/1874434620130726005

Blustein, D.L. (2008). The role of work in psychological health and well-being. A conceptual, historical, and public policy perspective. American Psychologist, 63, 228-240. https://doi.org/10.1037/0003-066X.63.4.228

Cartwright,S., \& Holmes, N. (2006). The meaning of work: The challenge of regaining employee engagement and reducing cynicism. Human Resource Management Review, 16, 199-208. https://doi.org/10.1016/j.hrmr.2006.03.012

Cascio, W.F. (2003). Responsible restructuring: Seeing employees as assets, not costs. Ivey Business Journal, 68, 1-5.

Chalofsky, N. (2003). An emerging construct for meaningful work. Human Resource Development International, 1, 69-83. https://doi.org/10.1080/1367886022000016785

DeHart, D., Webb, J., \& Cornman, C. (2009). Prevention of elder mistreatment in nursing homes: Competencies for direct-care staff. Journal of Elder Abuse \& Neglect, 21, 360-378. https://doi.org/10.1080/08946560903005174 


\section{Macrothink}

International Journal of Human Resource Studies

ISSN 2162-3058

2017, Vol. 7, No. 4

Demerouti, E. \& Bakker, A. B. (2011). The Job Demands-Resources model: Challenges for future research. South African Journal of Industrial Psychology, 37, 1-9. https://doi.org/10.4102/sajip.v37i2.974

Demerouti, E., Bakker, A. B., Nachreiner, F., \& Schaufeli, W. B. (2001). The job demands-resources model of burnout. Journal of Applied Psychology, 86, 499-512. https://doi.org/10.1037/0021-9010.86.3.499

Frankl, V.E. (1984). Man's search for meaning. New York: Pocket Books.

Garrick, A., Mark, A. S., Cathcart, S., Winwood, P. C., Bakker, A. B., \& Lushington, K. (2014). Psychosocial safety climate moderating the effects of daily job demands and recovery on fatigue and work engagement. Journal of Occupational and Organizational Psychology, 87, 694-714. https://doi.org/10.1111/joop.12069

Grant, A. M. (2007). Relational job design and the motivation to make a prosocial difference. Academy of Management Review, 32, 393-417. https://doi.org/10.5465/AMR.2007.24351328

Grant, A. M. (2008). The significance of task significance: Job performance effects, relational mechanisms, and boundary conditions. Journal of Applied Psychology, 93, 108-124. https://doi.org/10.1037/0021-9010.93.1.108

Grant, A. M., \& Parker, S. K. (2009). Redesigning work design theories: The Rise of Relational and Proactive Perspectives. Academy of Management Annals, 3, 317-375. https://doi.org/10.1080/19416520903047327

Hackman, J. R., \& Oldham, G. R. (1980). Work redesign. Reading, MA: Addison- Wesley.

Hakanen, J., Bakker, A. B., \& Schaufeli, W. B. (2006). Burnout and work engagement among teachers. Journal of School Psychology, 43, 495-513. https://doi.org/10.1016/j.jsp.2005.11.001

Harpaz, I., \& Fu, X. (2002). The structure and the meaning of work: A relative stability amidst change. Human Relations, 55, 639-668. https://doi.org/10.1177/0018726702556002

Havener, C. (1999). Meaning: The secret of being alive. Beaver's Pond Press.

Hayes, A. F. (2013). Introduction to mediation, moderation, and conditional process analysis. New York, NY: Guilford Press.

Helliwell, J., Layard, R., \& Sachs, J. (2017). World happiness report 2017, New York: Sustainable Development Solutions Network.

Hills, P., \& Argyle, M. (2002). The Oxford Happiness Questionnaire: a compact scale for the measurement of psychological well-being. Personality and Individual Differences, 33, 1073-1082. https://doi.org/10.1016/S0191-8869(01)00213-6

Holbeche, L., \& Springett, N. (2004). In search of meaning at work. Roffey Park Institute, Horsham.

Huta, V., \& Ryan, R.M. (2010). Pursuing pleasure or virtue: The differential and overlapping 
well-being benefits of hedonic and eudaimonic motives. Journal of Happiness Stud., 11, 735-762. https://doi.org/10.1007/s10902-009-9171-4

Huta, V., \& Waterman, A.S. (2014). Eudaimonia and its distinction from hedonia: Developing a classification and terminology for understanding conceptual and operational definitions. Journal of Happiness Stud., 15, 1425-1456. https://doi.org/10.1007/s10902-013-9485-0

Kahn, W. A. (1990). Psychological conditions of personal engagement and disengagement at work. Academy of Management Journal, 33, 692-724. https://doi.org/10.2307/256287

May, D. R., Gilson, R. L., \& Harter, L. M. (2004). The psychological conditions of meaningfulness, safety and availability and the engagement of the human spirit at work. Journal of Occupational and Organizational Psychology, 77, 11-37. https://doi.org/10.1348/096317904322915892

Michaelson, C., Pratt, M. G., Grant, A. M., \& Dunn, C. P. (2014). Meaningful work: Connecting business ethics and organization studies. Journal of Business Ethics, 121, 77-90. https://doi.org/10.1007/s10551-013-1675-5

Milliman, J., Czaplewski, A. J., \& Ferguson, J. (2003). Workplace spirituality and employee work attitudes: An exploratory empirical assessment. Journal of Organizational Change Management, 16(4), 426-447. https://doi.org/10.1108/09534810310484172

Nair, N., \& Vohra, N. (2009). Developing a new measure of work alienation. Journal of Workplace Rights, 14, 293-309. https://doi.org/10.2190/WR.14.3.c

Neck, C. P., \& Milliman, J. F. (1994). Thought self-leadership: Finding spiritual fulfilment in organizational life. Journal of managerial psychology, 9(6), 9-16. https://doi.org/10.1108/02683949410070151

Olivier, A. L., \& Rothmann, S. (2007). Antecedents of work engagement in a multinational company. SA Journal of Industrial Psychology, 33(3), 49-56. https://doi.org/10.4102/sajip.v33i3.396

Pratt, M. G., \& Ashford, B. E. (2003). Fostering meaningfulness in working and at work. In K. Cameron, J.E. Dutton, \& R.E. Quinn (Eds), Positive organizational scholarship: Foundations of a new discipline (pp. 308-327). San Fransisco: Berrett-Koehler.

Podsakoff, P. M., MacKenzie, S. B., Lee, J., \& Podsakoff, N. P. (2003). Common method bias in behavioral research: A critical review of literature and recommended remedies. Journal of Applied Psychology, 88, 879-903. https://doi.org/10.1037/0021-9010.88.5.879

Robertson, W. M. P. (2013). Doing meaning: a theoretical and grounded exploration of workplace relationships and meaningful work (doctoral dissertation Segal GraduateSchool): Beedle School of Business Faculty.

Rosso, B. D., Dekas, K. H., \& Wrzesniewski, A. (2010). On the meaning of work: A theoretical integration and review. Research in Organizational Behavior, 30, 91-127. https://doi.org/10.1016/j.riob.2010.09.001 
Ryan, R. M., \& Deci, E. L. (2000). On happiness and human potentials: A review of research on hedonic and eudaimonic well-being. Annual Review of Psychology, 52, 141-166. https://doi.org/10.1146/annurev.psych.52.1.141

Schaufeli, W. B., \& Bakker, A. B. (2004). Job demands, job resources and their relationship with burnout and engagement: A multi sample study. Journal of Organizational Behavior, 25, 293-315. https://doi.org/10.1002/job.248

Schaufeli, W. B., Bakker, A. B., \& Salanova, M. (2006). The measurement of work engagement with a short questionnaire: A cross-national study. Educational and Psychological Measurement, 66, 701-716. https://doi.org/10.1177/0013164405282471

Schaufeli, W. B., Leiter, M. P., Maslach, C., \& Jackson, S. E. (1996). The Maslach Burnout Inventory-General Survey. In C. Maslach, S.E. Jackson, \& M.P. Leiter (Eds.), Maslach Burnout Inventory. Palo Alto, CA: Consulting Psychologists Press.

Schaufeli, W. B., \& Taris, T. W. (2005). The conceptualization and measurement of burnout: Common ground and worlds apart. Work \& Stress, 19, 256-262. https://doi.org/10.1080/02678370500385913

Seligman, M. (2002). Authentic happiness. New York: Free Press.

Shantz, A., Alfes, K., \& Truss, C. (2014). Alienation from Work: Marxist Ideologies and $21^{\text {st }}$ Century Practice. International Journal of Human Resource Management, 25, 2529-2550. https://doi.org/10.1080/09585192.2012.667431

Steger, M. F., Dik, B. J., \& Duffy, R. D. (2012). Measuring meaningful work: The work and meaning inventory (WAMI). Journal of Career Assessment, 20, 322-337. https://doi.org/10.1177/1069072711436160

Tadic, M., Bakker, A. B., \& Oerlemans, W. G. M. (2013). Work happiness among teachers: a day reconstruction study on the role of self-confidence. Journal of School Psychology, 51, 735-750. https://doi.org/10.1016/j.jsp.2013.07.002

Thomas, K. W., \& Velthouse, B. E. (1990). Cognitive elements of empowerment: An "interpretive" model of intrinsic task motivation. Academy of Management Review, 15, 666-681.

Tims, M., Derks, D., \& Bakker, A. B. (2016). Job crafting and its relationship with person-job fit and meaningfulness: A three wave study. Journal of Vocational Behavior, 92, 44-53. https://doi.org/10.1016/j.jvb.2015.11.007

Veenhoven, R. (2008). Healthy happiness. Effects of happiness on physical health and the consequences for preventive health care. Journal of Happiness Studies, 9, 449-469. https://doi.org/10.1007/s10902-006-9042-1

Wilson, C. B., \& Davies, S. (2009). Developing relationships in long term care environments: The contribution of staff. Journal of Clinical Nursing, 18, 1746-1755. https://doi.org/10.1111/j.1365-2702.2008.02748.x 
World Economic Forum. (2016). The future of jobs; employment, skills and workforce strategy for the fourth industrial revolution. Cologny/Geneva: World Economic Forum.

World Economic Forum. (2017). Realizing human potential in the fourth industrial revolution: An agenda for leaders to shape the future of education, Gender and Work. Cologny/Geneva: World Economic Forum.

Wrzesniewski, A., \& Dutton, J. E. (2001). Crafting a job: Revisioning employees as active crafters of their work. Academy of management review, 26(2), 179-201.

Wrzesniewski, A., McCauley, C., Rozin, P., \& Schwartz, B. (1997). Jobs, careers, and callings: People's relations to their work. Journal of Research in Personality, 31, 21-33. https://doi.org/10.1006/jrpe.1997.2162

Yeoman, R. (2014). Meaningful work and workplace democracy: A philosophy of work and a politics of meaningfulness. Basingstoke: Palgrave Macmillan. https://doi.org/10.1057/9781137370587

\section{Copyright Disclaimer}

Copyright for this article is retained by the author(s), with first publication rights granted to the journal.

This is an open-access article distributed under the terms and conditions of the Creative Commons Attribution license (http://creativecommons.org/licenses/by/4.0/). 